\title{
Phytophthora capsici Epidemic Dispersion on Commercial Pepper Fields in Aguascalientes, Mexico
}

\author{
Adrián Zapata-Vázquez, ${ }^{1}$ Mario Sánchez-Sánchez, ${ }^{1}$ \\ Alicia del-Río-Robledo, ${ }^{1}$ Héctor Silos-Espino, ${ }^{1}$ \\ Catarino Perales-Segovia, ${ }^{1}$ Silvia Flores-Benítez, ${ }^{1}$ \\ Mario Martín González-Chavira, ${ }^{2}$ and Luis Lorenzo Valera-Montero ${ }^{1}$ \\ ${ }^{1}$ Instituto Tecnológico El Llano Aguascalientes, Ags., Km 18, Carr. Ags.-S.L.P., 20330, Mexico \\ ${ }^{2}$ CIRCE-INIFAP, Km 6.5 Carr. Celaya-San Miguel de Allende, 38110 Celaya, Gto., Mexico \\ Correspondence should be addressed to Luis Lorenzo Valera-Montero, lvalera2003@yahoo.com
}

Received 1 November 2011; Accepted 18 January 2012

Academic Editor: Sarabjit Mastana

Copyright (C 2012 Adrián Zapata-Vázquez et al. This is an open access article distributed under the Creative Commons Attribution License, which permits unrestricted use, distribution, and reproduction in any medium, provided the original work is properly cited.

\begin{abstract}
Chili pepper blight observed on pepper farms from north Aguascalientes was monitored for the presence of Phytophthora capsici during 2008-2010. Initially, ELISA tests were directed to plant samples from greenhouses and rustic nurseries, showing an $86 \%$ of positive samples. Later, samples of wilted plants from the farms during the first survey were tested with ELISA. The subsequent survey on soil samples included mycelia isolation and PCR amplification of a $560 \mathrm{bp}$ fragment of ITS-specific DNA sequence of $P$. capsici. Data was analyzed according to four geographical areas defined by coordinates to ease the dispersal assessment. In general, one-third of the samples from surveyed fields contained P. capsici, inferring that this may be the pathogen responsible of the observed wilt. Nevertheless, only five sites from a total of 92 were consistently negative to $P$. capsici. The presence of this pathogen was detected through ELISA and confirmed through PCR. The other two-thirds of the negative samples may be attributable to Fusarium and Rhizoctonia, both isolated instead of Phytophthora in these areas. Due to these striking results, this information would be of interest for local plant protection committees and farmers to avoid further dispersal of pathogens to new lands.
\end{abstract}

\section{Introduction}

Chili pepper blight due to Phytophthora capsici and Verticillium spp. [1] has been present in commercial pepper fields in Aguascalientes and neighboring states in Mexico [2]. Nevertheless, there is a lack of detailed data on the degree of incidence related to spatial distribution from Mexican areas where this Phytophthora is prevalent. Some approaches have been developed for Aguascalientes [3], Zacatecas [2], and Chihuahua $[4,5]$. From these studies only one [4] deals with some indicators of incidence of Phytophthora capsici according to one region. Since pepper blight is so devastating for pepper farms, it is worthy to study its incidence through a survey [6]. Therefore, the purpose of this work is to add more information on the spatial distribution of this pathogen on the northern part of Aguascalientes and describe its actual incidence on chili pepper farms.

\section{Materials and Methods}

2.1. Plant and Soil Sampling. Whole plants showing severe wilting, collapsed still-green leaves, and root rot were collected from commercial fields. All of the plants collected in the field showed flowers and fruits. Additionally, 36 plantlet samples from two greenhouses and 16 rustic nurseries were included due to suspicious contamination only for ELISA testing (not for fungi isolations). Collection of plant samples in the field was done five times (once each month) on the same fields (92 geographical positions) from April to September 2008. Some data was missing for the first time of sampling (26 sites) due to late planting. Data was clustered into four groups according to geographic closeness and access roads. During 2009, soil samples from 82 sites within chilli pepper fields were taken with a post hole digger from $0-30$ and $30-60 \mathrm{~cm}$ deep diggings, rending a total of 
164 samples. Both plant and soil samples were taken from northern Aguascalientes (Cosío, Tepezalá, Rincón de Romos and Pabellón de Arteaga) within the parallels $22^{\circ} 00^{\prime} 47^{\prime \prime}$ and $22^{\circ} 23^{\prime} 25^{\prime \prime}$ North and $102^{\circ} 14^{\prime} 57^{\prime \prime}$ and $102^{\circ} 19^{\prime} 11^{\prime \prime}$ West, where most chilli pepper fields were found. Coordinates for geopositioning the fields of the collected plant and soil samples were recorded.

\subsection{ELISA Detection of Phytophthora on Wilted Chili Plants.} Immunological detection through ELISA was performed as described by the supplier of the reagent kit for Phytophthora detection in plants (CAB 92600/0500 and ACC00948 from AGDIA). Stems of plants showing root rot (wilted) and controls with normal appearance were sliced with a knife and ground with a mortar. After grinding, $100 \mu \mathrm{L}$ of sap was placed in Eppendorf tubes plus $1 \mathrm{~mL}$ of the extraction buffer GEB2 from the kit and mixed gently. At the same time, mycelia from Phytophthora capsici cultures were used as positive control together with the positive control included in the kit. A scrap from cultures about $1 \mathrm{~cm}^{2}$ and $500 \mu \mathrm{L}$ GEB2 were placed inside an Eppendorf tube and ground with a crystal bar. After grinding, tubes were left in vertical position for $10 \mathrm{~min}$ to allow particles to sink and reach the bottom. The rest of the protocol was followed according to the directions of the supplier.

2.3. Fungal Isolates from Wilted Chili Plants. Fungi isolates were obtained from crown segments of wilted plants with rot roots and lesions on the stem that retained leaves and fruits. Plants were taken fresh from commercial fields (22 during 2010) and washed using tap water and commercial soap. Segments $(5-10 \mathrm{~mm})$ from the stem having visible lesions were cut with a razor blade and disinfected with $1 \%$ sodium hypochlorite (5-10 $\mathrm{min})$ and rinsed with sterile distilled water for 1-2 min; then, the segments were dried on sterile paper napkins. In order to check for the microorganisms present in the plants, samples were placed on V8-agar $\left(200 \mathrm{~mL} \mathrm{~V} 8+800 \mathrm{~mL}\right.$ distilled water $+0.2 \mathrm{~g} \mathrm{CaCO}_{3}+20 \mathrm{~g}$ agar $+4 \mathrm{~g}$ sucrose) for 4-7 days in the darkness. In order to obtain Phytophthora, selective medium PARP (V8-agar + $5 \mathrm{mg}$ Pimaricin $+250 \mathrm{mg}$ Ampicillin sodium $+10 \mathrm{mg}$ Rifamycin sodium + 50 mg PCNB) [7-9].

\subsection{Fungal Isolates from Soil}

Media Used. Acidified Potato Dextrose Agar (PDA $+16 \mathrm{~g}$ agar $+250 \mu \mathrm{L}$ lactic acid) and a PARP variant (V8-agar $+5 \mathrm{mg}$ Pimaricin + $250 \mathrm{mg}$ Ampicillin sodium + $10 \mathrm{mg}$ Rifamycin sodium $+30 \mathrm{mg}$ Cefalexin) were fixed. In order to count fungi CFUs, one gram of soil was dissolved on sterile water $(10 \mathrm{~mL}$ final volume) and vortexed. Once the soil particles descended by gravity, a volume of the supernatant was taken and diluted $1 / 10$. From that dilution $1 \mathrm{~mL}$ was spread over the acidified PDA and left for $48 \mathrm{~h}$ at room temperature. Colonies were randomly chosen by marking dots with permanent marker, placing a 25-point grid (as a guide) on the bottom of the Petri dish. Microscopic view ( $4 \mathrm{x}$ objective lens) was centered on each dot for colony quantification. Fungi genera were determined as previously described [10] using a 40x objective lens.

Phytophthora capsici was isolated using autoclaved fresh peanuts as trap. First, $16 \mathrm{~g}$ of soil samples plus $10 \mathrm{~mL}$ sterile water was placed in Petri dishes. Then, peanut halves were placed in the Petri dishes together with the soil samples and incubated at room temperature during $48 \mathrm{~h}$. After incubation, peanut halves were placed on the PARP variant for at least $48 \mathrm{~h}$, and once a culture was identified as Phytophthora, monosporal or hyphal tip cultures were transferred to a fresh PARP medium, as many times as required, until isolated. Half-an-inch agar dishes containing mycelia from the isolates were cultivated on acidified PDA Petri dishes covered with $\approx 6 \mathrm{~g}$ ground peanut dried at $36^{\circ} \mathrm{C}$ plus $6 \mathrm{~mL}$ sterile water with antibiotics $(30 \mathrm{mg} / \mathrm{L}$ Cefalexin + $30 \mathrm{mg} / \mathrm{L}$ Rifampicin $+5 \mathrm{mg} / \mathrm{L}$ Pimaricin) for $24 \mathrm{~h}$.

2.5. PCR Test of Isolates from Soil. DNA from soil isolates was extracted as described elsewere [11]. Briefly, mycelia desiccated at $36^{\circ} \mathrm{C}$ for $24 \mathrm{~h}$ were ground on a mortar with liquid nitrogen. Then, $100 \mathrm{mg}$ of ground mycelia plus $800 \mu \mathrm{L}$ of extraction buffer (0.2 M Tris, 0.05 M EDTA pH 7.5, 0.2 M $\mathrm{NaCl}, 2 \% \mathrm{CTAB}$ and $60 \mathrm{~mL} 5 \%$ Sarcosyl) was placed into a $1.5 \mathrm{~mL}$ Eppendorf tube. Tubes were incubated at $65^{\circ} \mathrm{C}$ during 15 min under continuous gently shaking. After that, $600 \mu \mathrm{L}$ phenol: chloroform : iso-amyl alcohol $(24: 25: 1)$ was added to the tubes and incubated at $-20^{\circ} \mathrm{C}$ for $10 \mathrm{~min}$. Tubes were centrifugated at $13,000 \mathrm{~g}$ during $15 \mathrm{~min}$. The supernatant was placed in a fresh tube in order to repeat the previous step. Next, $600 \mu \mathrm{L}$ of $70 \%$ ethanol was added and incubated overnight at $-20^{\circ} \mathrm{C}$. After that, tubes were centrifugated at $13,000 \mathrm{~g}$ during $15 \mathrm{~min}$ and the supernatant was discarded. Pellets were washed with $70 \%$ ethanol and dried at room temperature. DNA was resuspended in $40 \mu \mathrm{L}$ TE.

PCR was performed as described by [12]. The primers used amplify a $560 \mathrm{bp}$ fragment from specific Phytophthora capsici ITS sequences (PC-1: 5'-GTCTTG TACCCTATCATGGCG-3' and PC-2: 5'-CGCCACAGCAG GAAAAGCATT-3'). Reaction mixture included $12.5 \mu \mathrm{L} 2 \mathrm{x}$ GoTaq Green Master Mix (Promega 2800, Woods Hollow Road Madison WI 53711 USA), $2.5 \mu \mathrm{L}$ from both primers $(10 \mu \mathrm{M} \mathrm{PC}-1$ and PC-2), $3 \mu \mathrm{L}$ of genomic DNA, and $7 \mu \mathrm{L}$ of nuclease-free water (Promega) for a $25 \mu \mathrm{L}$ final volume. Temperatures of the thermocycler were set as follows: preheat at $94^{\circ} \mathrm{C}$ during $4 \mathrm{~min} ; 35$ cycles including $30 \mathrm{sec}$ at $94^{\circ} \mathrm{C}$ for denaturing, $30 \mathrm{sec}$ at $70^{\circ} \mathrm{C}$ for annealing, and $1.5 \mathrm{~min}$ at $72^{\circ} \mathrm{C}$ for polymerization; a final extension at $72^{\circ} \mathrm{C}$ for 7 minutes. Once the PCR was concluded, samples were run in $1.5 \%$ agarose SB gel, with $240 \mathrm{~V}$ during one hour.

2.6. Statistical Analysis. ELISA results from greenhouse and nurseries were combined and analyzed using chi-square for an equal chance of a positive/negative response $\left(\chi^{2}, 1 \mathrm{df}\right.$, $e_{1}$ and $\left.e_{2}=50 \%\right)$. ELISA results from four geographical zones were analyzed as a contingency table. In both cases, the observed significance level $(P)$ was recorded. 
TABle 1: Results from ELISA test for Phytophthora capsici on chili pepper plant samples from greenhouses, nurseries, and farms located in four geographical zones in the northern area of Aguascalientes, Mexico.

\begin{tabular}{|c|c|c|c|c|c|c|c|}
\hline ELISA & Greenhouse & Nursery & $\mathrm{G}+\mathrm{N}$ & Zone 1 & Zone 2 & Zone 3 & Zone 4 \\
\hline Positive & 5 & 26 & 31 & 54 & 22 & 18 & 98 \\
\hline Negative & 5 & 0 & 5 & 96 & 34 & 37 & 92 \\
\hline$\%(+)$ & 50 & 100 & 86.1 & 36.0 & 39.3 & 32.7 & 51.6 \\
\hline$\chi^{2}=$ & & & 18.78 & \multicolumn{4}{|c|}{11.38} \\
\hline$P=$ & & & $1.47 \mathrm{E}-05$ & \multicolumn{4}{|c|}{0.0098} \\
\hline
\end{tabular}

TABle 2: Fungi and yeast genera identified on isolates from lesions of wilted plants with root rot of chilli pepper collected in the northern area of Aguascalientes, Mexico.

\begin{tabular}{lcc}
\hline Genera & Counts & Percentage \\
\hline Phytophthora & 7 & 1.76 \\
Fusarium & 42 & 10.58 \\
Rhizopus & 128 & 32.24 \\
Alternaria & 36 & 9.07 \\
Aspergillus & 53 & 13.35 \\
Penicillium & 85 & 21.41 \\
Candida & 20 & 5.04 \\
Rhizoctonia & 26 & 6.55 \\
Total & 397 & 100 \\
\hline
\end{tabular}

\section{Results}

3.1. ELISA Detection of Phytophthora on Wilted Chili Plants. Plantlets from greenhouse and nursery: initially, 36 samples were selected from plantlets showing either wilting or lesions from two greenhouses (10 samples from cultivars: Caloro, Hungaro, Guajillo, Pasilla, and Puya), and 16 rustic nurseries from poor farmers (26 samples from the same cultivars but Caloro) were tested for the presence of the pathogen. Only one sample out of six from the first greenhouse was positive to the presence of Phytophthora while the four samples from the second greenhouse were all positives. Furthermore, all of the samples from nurseries were positive to the test. This was a possible indication that these $86 \%$ positive samples may be the starting point for soil contamination of the Aguascalientes chilli fields. Since previous field trips (in 2007) have shown that there was no field free of wilted plants with root rot (5-90\%) and information of Phytophthora capsici dissemination in chilli fields of Aguascalientes is rather scarce, the expected values of positives were at least $50 \%$ from either the nurseries or the greenhouses (data combined as $\mathrm{G}+\mathrm{N}$ in Table 1 ).

Plants from the fields: data from the five dates of sampling was combined within each cluster or zone. Zones are described from north to south. In the first zone, located within $22^{\circ} 21^{\prime} 27^{\prime \prime}$ and $22^{\circ} 23^{\prime} 19^{\prime \prime}$ North and $102^{\circ} 15^{\prime} 56^{\prime \prime}$ and $102^{\circ} 17^{\prime} 46^{\prime \prime}$ West, $36 \%$ of the samples were positive. In the second zone, placed within $22^{\circ} 20^{\prime} 43^{\prime \prime}$ and $22^{\circ} 21^{\prime}$ $12^{\prime \prime}$ North and $102^{\circ} 14^{\prime} 57^{\prime \prime}$ and $102^{\circ} 16^{\prime} 58^{\prime \prime}$ West, $39.3 \%$ were positive. In the third zone, placed within parallels $22^{\circ}$ $18^{\prime} 26^{\prime \prime}$ and $22^{\circ} 18^{\prime} 56^{\prime \prime}$ North and $102^{\circ} 15^{\prime} 40^{\prime \prime}$ and $102^{\circ}$ $16^{\prime} 06^{\prime \prime}$ West, $32.7 \%$ were positive. Finally, in the fourth zone located within $22^{\circ} 18^{\prime} 26^{\prime \prime}$ and $22^{\circ} 18^{\prime} 57^{\prime \prime}$ North and $102^{\circ} 15^{\prime} 40^{\prime \prime}$ and $102^{\circ} 16^{\prime} 06^{\prime \prime}$ West $51.6 \%$ were positive. Zones were analyzed as contingency table not including either greenhouse or nursery data (Table 1). Zone 4 had the highest percentage of positives to Phytophthora. Nevertheless, this data does not reflect the damage observed on the fields because they were not surveyed for the number of wilted plants or production of commercial fruits. In some cases, the damage was so intense that the whole field was plowed before the crop cycle was completed. Taking together the results of the four zones, only five out of 92 geographical sites consistently did not show the presence of the pathogen on the successive sampling. This is an alarming result, since most of the farmers move to new fields that were not used for chilli pepper, leaving contaminated patches with the pathogen in the northern Aguascalientes.

3.2. Fungal Isolates from Wilted Chili Plants. Plants for fungi isolation during 2010 were collected from the same geographical area (176 plants from 22 different fields) as the previous two years; the criteria for previous plant sampling prevailed. Since this type of wilting is due to the attack of fungal complexes, Phytophthora was not the only genera isolated. Actually, its counts appear to be lower, probably because the others are aggressive at the time of colonizing the media. Fusarium and Rhizoctonia have their own contributions for the wilting and root rot as previously described [1]. The rest may be saprophytes or contaminants of the rotten areas (Table 2).

The results of isolation not necessarily reflect all of the events of the process from infection to death of chilli plants due to Phytophthora. González-Chavira [13] initially tried to establish a relationship in Guanajuato (Mexico) of this kind but the number of Phytophthora isolates was rather low (2\%) as compared to Fusarium spp. (65\%) and Rhizoctonia solani (33\%). Later, this author moved to PCR for detection of Phytophthora from fresh plants [14]. Some of the same pathogens were found as a complex on plants showing similar symptoms (brown-black discolored collar with root rots causing permanent wilting and plant death) in Europe. A three-year survey on pepper showing wilting and discoloration (755 plants from 120 farms, Spain) showed that Phytophthora capsici (18\%), Sclerotium rolfsii (83\%), Rhizoctonia solani, Verticillium dahliae (33\%), and other potential pathogens were present [6]. 
TABle 3: Counts of Phytophthora capsici cultures from soil samples taken in four geographical zones in the northern area of Aguascalientes, Mexico.

\begin{tabular}{lcccccc}
\hline Media & Zone 1 & Zone 2 & Zone 3 & Zone 4 & $(+)$ & Total \\
\hline Acidic PDA & 29 & 3 & 10 & 2 & 44 & 164 \\
PARP-V8* & 4 & 0 & 2 & 1 & 7 & 27 \\
PARP-PCR confirm & 2 & 1 & 0 & 0 & 3 & 25 \\
Peanut-PCR confirm & 3 & 1 & 2 & 1 & 7 & 164 \\
\hline
\end{tabular}

${ }^{*}$ Counts in Petri dish.

** Total soil samples or dishes.

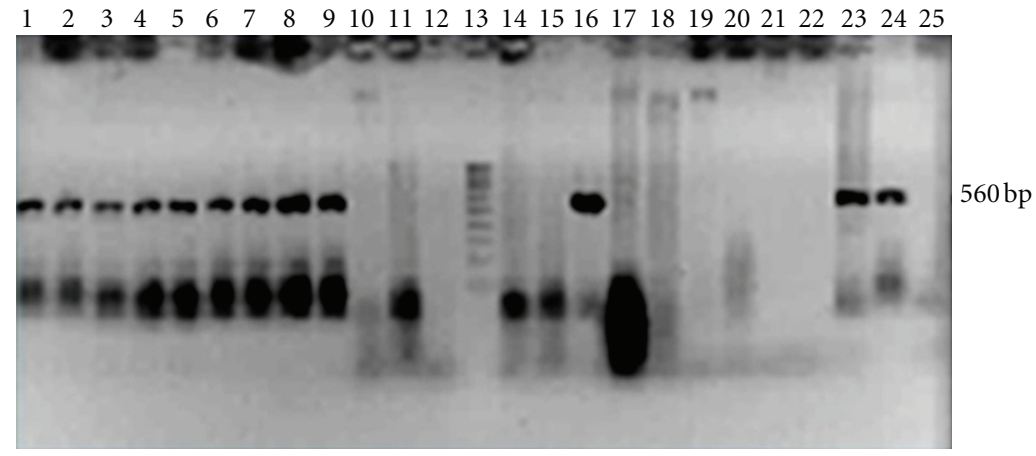

FIGURe 1: Positive detection of Phytophthora capsici from soil samples through PCR amplification of a specific 560 bp ITS fragment (lanes 1-7). Lane 13: molecular weight marker, lanes 24 and 25: positive and negative control, respectively. Lanes 8, 9, 16, and 23 are duplicates from the same samples.

3.3. Fungal Isolates from Soil and PCR Confirmation of P. capsici. Initial positive counts on acidic PDA of Phytophthora capsici were 28\% (46 out of 164 soil samples), Fusarium sp. 45.7\% (75/164), and Rhizoctonia sp. 17.7\% (29/164). Other potential pathogens (Verticillium, Pythium, and Rhizopus) were not recorded due to their low number. Specific trapping with peanut and Phytophthora capsici isolation on PARP, allowed confirming its presence through PCR (Figure 1; Table 3). In this case, it was difficult to obtain positives without trapping Phytophthora, since only $1.8 \%$ was evident from 164 samples. Trapping with peanut helped in the detection, since $28 \%$ of a subsample (25 soil samples) was positive.

\section{Conclusions}

Plantlets positive to Phytophthora taken either from greenhouse or nursery were recorded as $86 \%$ (31/36); this figure indicates that they may be the primary source for the local spreading of the pathogen in pepper fields of Aguascalientes.

ELISA test showed that one-third of pepper blight samples from the field were positive to the presence of $P$. capsici. Nevertheless, most of the farms showed at least one positive during successive sampling of the same geographical site. Exemptions to the rule were five farms, corresponding to five geographical sites from a total of 92. Therefore, most farms from north Aguascalientes during 2008-2010 were detected as contaminated with Phytophthora capsici, distributed approximately the same on three out of four geographical zones. Only zone 4 showed about $50 \%$ of ELISA positives. Confirmation on the presence of Phytophthora through pathogen isolation and PCR supports ELISA data, although they were done one year later.

Wilting of the two-thirds not positive samples to Phytophthora may be attributable to fungus Fusarium and Rhizoctonia isolated alone or as a complex in this work. Other work includes to Verticillium and Pythium in the complex [1]. Since our surveys covered most of the pepper farms on the north Aguascalientes and all of the surveyed farms had wilted spots with similar symptoms (wilting with hanging still-green leaves and root rot), attention and preventive procedures should be devoted to avoid spreading of more than one pathogen associated to the blight to new farms. Additionally, detailed data on local dynamics of the disease are necessary $[5,15]$ to support the work of the local committee for plant protection CESAVEA.

\section{Acknowledgments}

The authors wish to thank Dirección General de Educación Tecnologica for the Grant provided (592.07-P) for this research. Thanks are due to Dr. Leticia E. Medina Esparza for lab training of A. Zapata Vázquez at the ITEL. The authors are grateful to M.S. Brenda Zulema Guerrero for lab training to M. Sánchez-Sánchez at CIRCE-INIFAP, Celaya. Thanks are also due to Dr. Onésimo Moreno Rico from the UAA for providing a Phytophthora capsici isolate used as a positive control for this work and training of Blanca Idalia Ortiz Sánchez and Alberto Castañeda Hernández. Finally, they are indebted to Ing. Refugio Lucio Castañeda and M.S. Miguel 
Angel Moya Ovalle (CESAVEA) for help when tracking hidden pepper fields.

\section{References}

[1] R. Velázquez-Valle and M. M. Medina-Aguilar, "Integrated disease management," in Dry Chili Pepper Production Technology, p. 232, CAEZ-CIRNOC-INIFAP, Technical Book, 2006.

[2] R. Velázquez-Valle, M. M. Medina-Aguilar, and J. J. Luna Ruiz, "Symptoms and pathogen genera associated to pepper root rot in the Central-North Mexico. (Sintomatología y géneros de patógenos asociados con las pudriciones de raíz del chile Capsicum annuum L. en el Norte-Centro de México)," La Revista Mexicana de Fitopatología, vol. 19, pp. 175-181, 2001.

[3] V. M. Rodríguez-Moreno, J. J. Luna-Ruiz, P. Valle-García, M. Tiscareño-López, and J. A. Ruiz-Corral, "Pathogenic and sexual characterization of Phytophthora capsici Leonian and spatial distribution in central-north Mexico through a GPS. (Caracterización patogénica y sexual de Phytophthora capsici Leonian y análisis de su distribución espacial en el centro-norte de México mediante un sistema de información geográfica)," La Revista Mexicana de Fitopatología, vol. 22, pp. 72-81, 2004.

[4] C. Guigón-López and P. A. González-González, "Regional survey of chili pepper (Capsicum annuum, L.) diseases and their behavior in south Chihuahua, Mexico. (Estudio regional de las enfermedades del chile Capsicum annuum, L. y su comportamiento temporal en el sur de Chihuahua, México)," La Revista Mexicana de Fitopatología, vol. 19, pp. 49-56, 2001.

[5] H. V. Silva-Rojas, S. P. Fernández-Pavía, C. Góngora-Canul, B. C. Macías-López, and G. D. Ávila-Quezada, "Spatiotemporal distributions of pepper (Capsicum annuum L.) wilt in Chihuahua and identification of the causal agent Phytophthora capsici Leo. (Distribución espacio temporal de la marchitez del chile Capsicum annuum L. en Chihuahua e identificación del agente causal Phytophthora capsici Leo)," La Revista Mexicana de Fitopatología, vol. 27, pp. 134-147, 2009.

[6] J. L. Andrés-Ares, A. Rivera-Martínez, F. Pomar-Barbeito, and J. Fernández-Paz, "Telluric pathogens isolated from blighted pepper (Capsicum annuum L.) plants in northwestern Spain," Spanish Journal of Agricultural Research, vol. 3, pp. 326-330, 2005.

[7] A. J. Ferguson and S. N. Jeffers, "Detecting multiple species of Phytophthora in container mixes from ornamental crop nurseries," Plant Disease, vol. 83, no. 12, pp. 1129-1136, 1999.

[8] H. Masago, M. Yoshikawa, M. Fukada, and N. Nakanishi, "Selective inhibition of Pythium spp. on a medium for direct isolation of Phytophthora spp. from soil and plants," Phytopathology, vol. 67, pp. 425-428, 1977.

[9] N. Osterbauer, "Guidelines for isolation by culture and morphological identification of Phytophthora ramorum," SOP 2/27/2003, Department of Agriculture, 2004.

[10] H. L. Barnett and B. B. Hunter, Illustrated Genera of Imperfect Fungi, Burgess, Minneapolis, Minn, USA, 4th edition, 1972.

[11] C. T. Monreal-Vargas, Methods for diagnosing viral, bacterial and fungal diseases on horticultural crops. (Desarrollo de métodos de diagnóstico molecular de enfermedades virales, bacterianas y fúngicas en hortalizas), M.S. thesis, Instituto Potosino de Investigación Científica y Tecnológica, San Luis Potosi, Mexico, 2005.

[12] Z. G. Zhang, Y. Q. Li, H. Fan, Y. C. Wang, and X. B. Zheng, Molecular Detection of Phytophthora capsici in Infected
Plant Tissues, Soil and Water, Department of Plant Pathology, Nanjing Agricultural University, China, 2006.

[13] M. M. González-Chavira, Chilli pepper wilt control: an integral research example. (Control de la marchitez del chile: Un ejemplo de investigación integrada. Documento de capacitación de Comités Estatales de Sanidad Vegetal), CIRCE-INIFAP, Mexico, 2008.

[14] L. Rico-Guerrero, S. Medina-Ramos, C. I. Muñoz-Sánchez, L. Guevara-Olvera, and R.G. Guevara-González, "Phytophthora capsici detection in chilli plants (Capsicum annuum L.) through PCR. (Detección de Phytophthora capsici Leonian en plantas de chile Capsicum annuum L., mediante PCR)," La Revista Mexicana de Fitopatología, vol. 22, pp. 1-6, 2004.

[15] J. B. Ristaino, R. P. Larkin, and C. L. Campbell, "Spatial and temporal dynamics of Phytophthora epidemics in commercial bell pepper fields," Phytopathology, vol. 83, no. 12, pp. 13121320, 1993. 

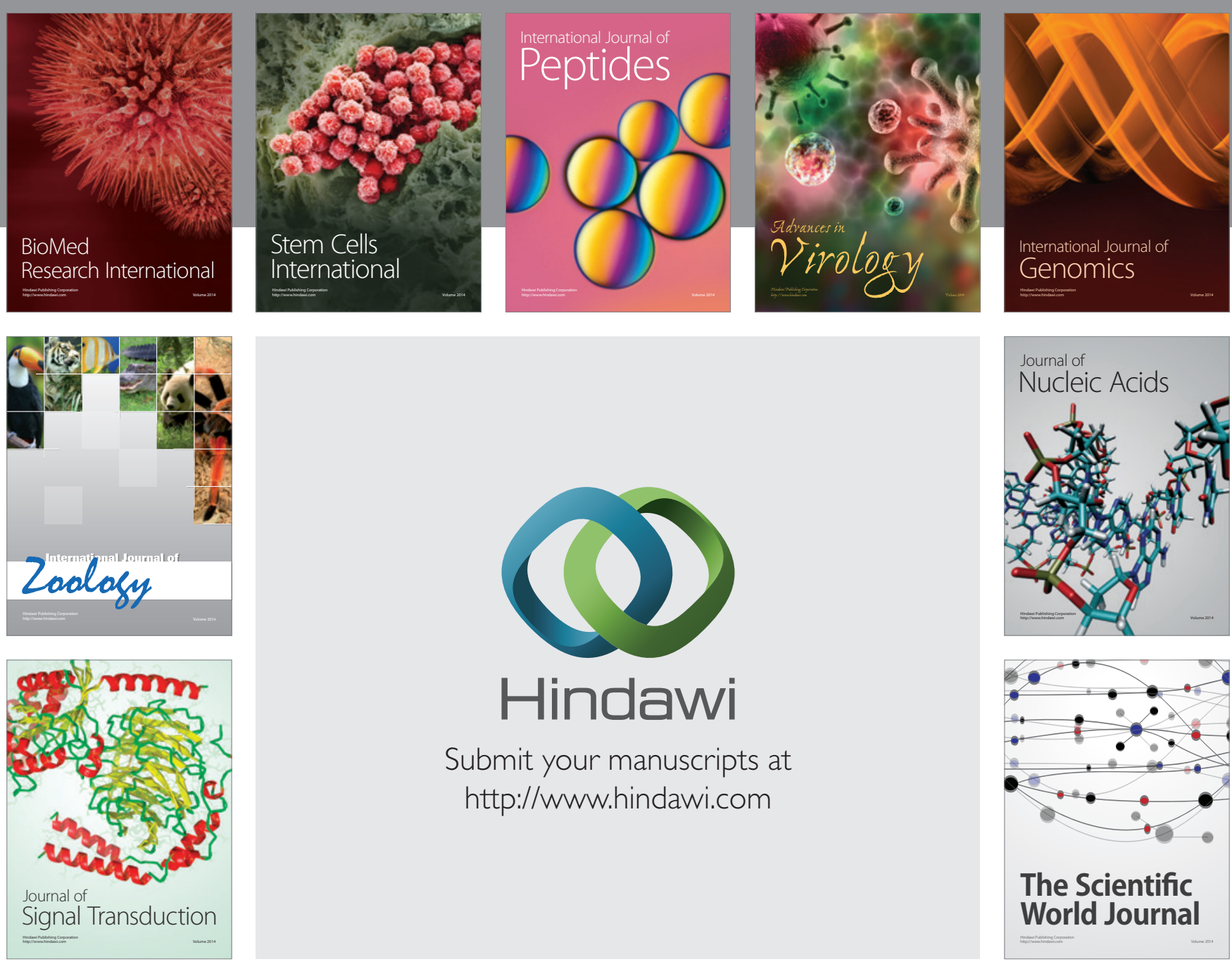

Submit your manuscripts at

http://www.hindawi.com
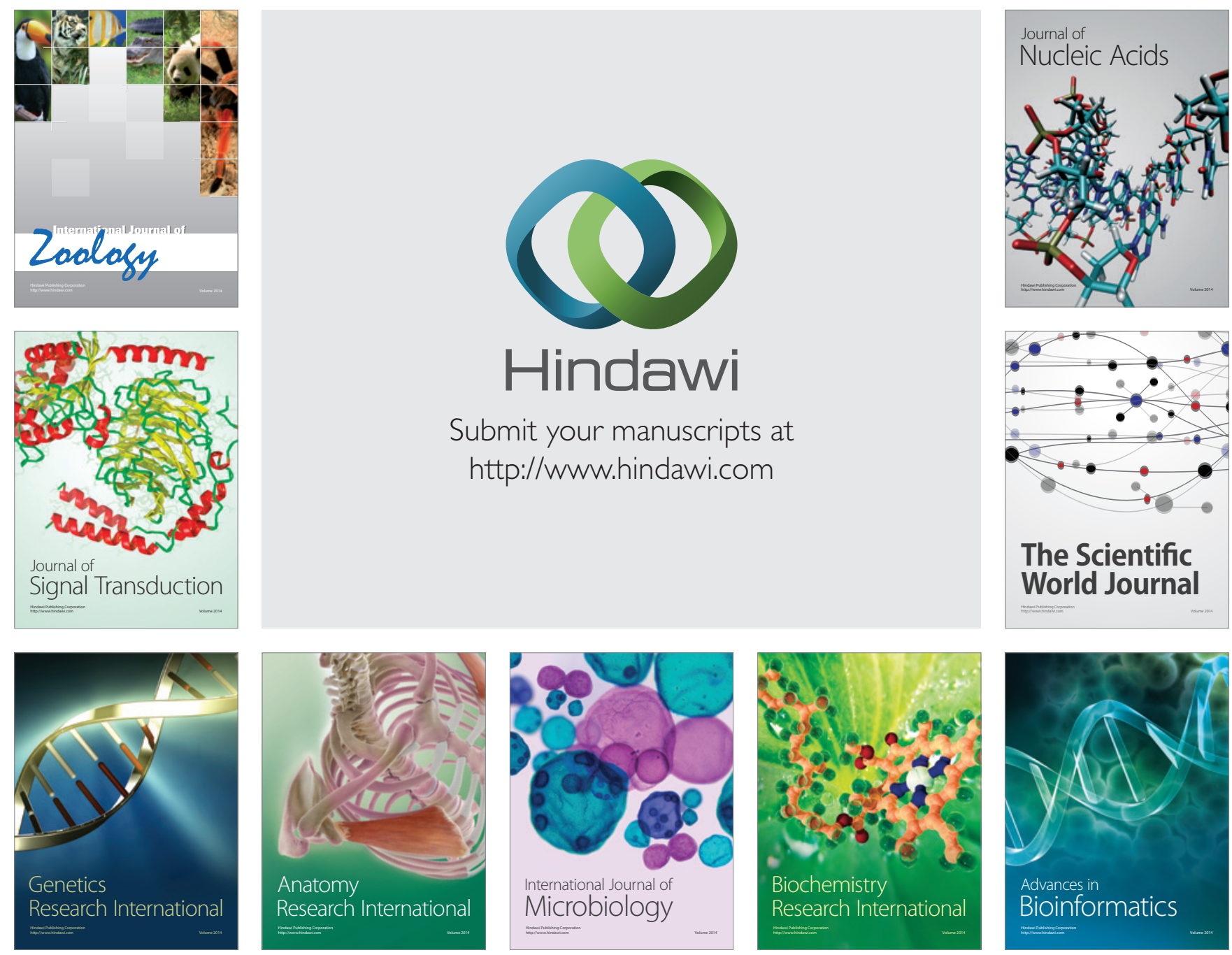

The Scientific World Journal
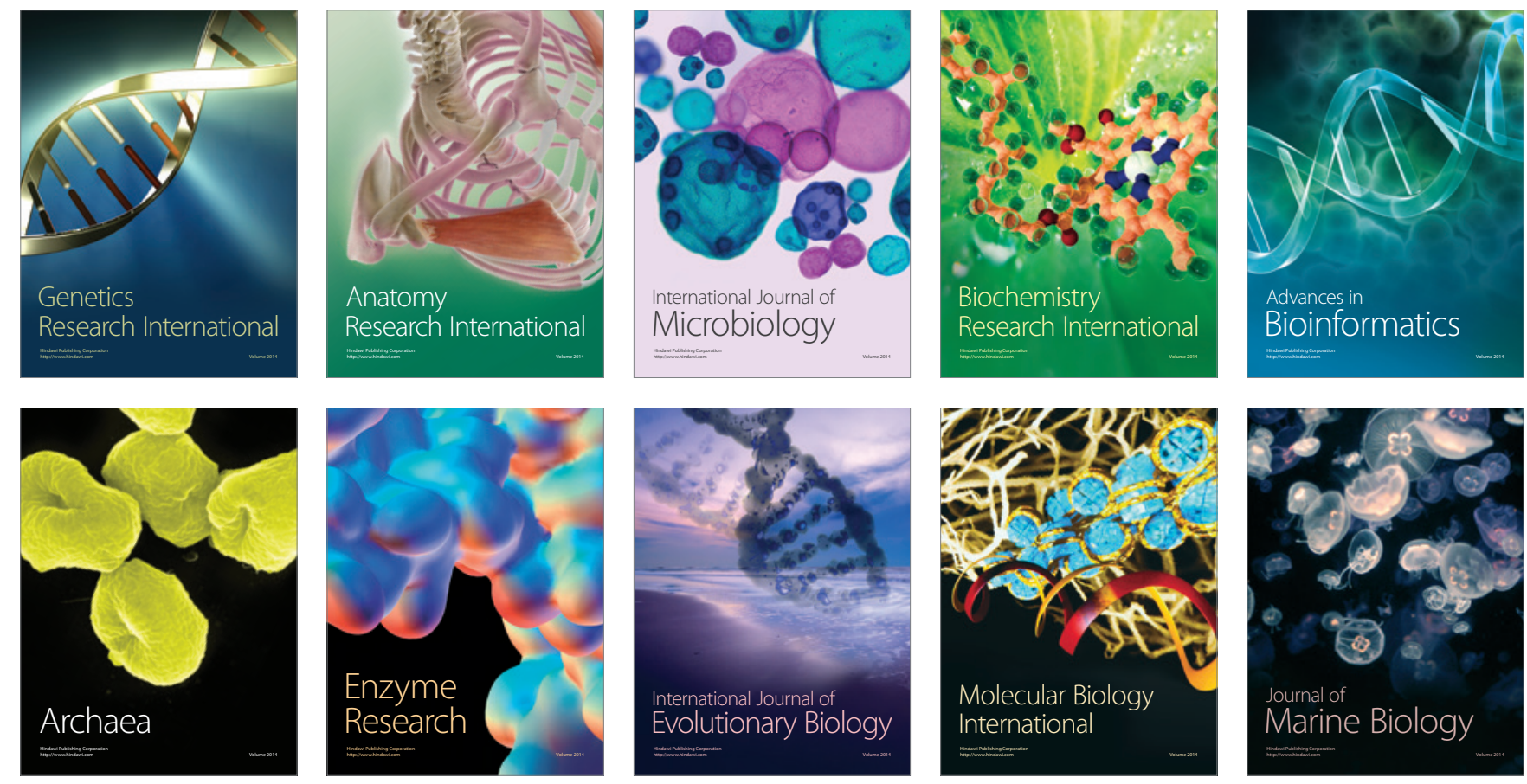